\title{
Summary of the Special Analysis of Savannah River Depleted Uranium Trioxide Demonstrating the Before and After Impacts on the DOE Order 435.1 Performance Objective and the Peak Dose
}

\section{Introduction and Executive Summary}

The report "Summary of the Preliminary Analysis of Savannah River Depleted Uranium Trioxide," Document DOE/NV/25946--1090, was conducted for waste stream (SVRSURANIUM03, Revision 2). Note 1: In January 2011, Savannah River notified the Waste Acceptance Review Panel that the waste stream should be Revision 1 vs. Revision 2 . The preliminary analysis of document DOE/NV/25946--1090 was performed to determine the acceptability of the waste stream for shallow land burial at the Area 5 Radioactive Waste Management Site (RWMS) at the Nevada National Security Site (NNSS). The Savannah River Depleted Uranium Trioxide waste stream requires a special analysis because the waste stream's sum of fractions exceeds one. The ${ }^{99} \mathrm{Tc}$ activity concentration is 98 percent of the NNSS Waste Acceptance Criteria (U.S. Department of Energy, National Nuclear Security Administration Nevada Site Office, 2010) and the largest single contributor to the sum of fractions.

This report summarizes the special analysis (SA) of the Savannah River Depleted Uranium Trioxide waste stream (SVRSURANIUM03, Revision 1; see note 1 above) demonstrating the before and after impacts of the waste stream to the DOE Order 435.1 performance objective at the disposal facility, and the peak dose. It is important to note the Nevada Division of Environmental Protection (NDEP) requested this SA and asked the Nevada Site Office (NSO) to run the SA deterministically and assume that all the model conditions remain the same regardless of the length of time to the peak dose. Although the NDEP accepts that DOE Order 435.1 requires a compliance period of 1,000 years, it also requested to know what year, if any, the specific DOE performance objectives will be exceeded.

Given the NDEP's requested model conditions, the SA demonstrates the ${ }^{222} \mathrm{Rn}$ peak dose will occur in about 2 million years and will exceed the performance objective in about 6,000 years. The $0.25 \mathrm{mSv} \mathrm{y}^{-1}$ all-pathway performance objective was not exceeded for the resident scenario after reaching the 4 million year peak dose. When the NDEP requested this special analysis, both the NSO and NDEP verbally acknowledged the magnitude and timing of peak results from the extended duration analysis represent model performance and should not be considered meaningful representations of future disposal site performance.

\section{Material and Methods}

The waste stream inventory is estimated from the waste profile (Savannah River Nuclear Solutions, 2010) (Table 1). The representative activity concentration is assumed to be the median of a lognormal distribution. The upper limit activity concentration is assumed to be the $95^{\text {th }}$ percentile. The total waste stream activity is assumed to be the product of the activity concentration and the waste stream volume, $3,800 \mathrm{~m}^{3}$. 
Table 1. Savannah River Depleted Uranium Trioxide Waste Stream geometric mean inventory and geometric standard deviation.

\begin{tabular}{|c|c|c|c|c|c|c|c|}
\hline \multirow[b]{2}{*}{ Nuclide } & \multicolumn{3}{|c|}{ Activity Concentration } & \multicolumn{3}{|c|}{ Total Activity } & \multirow{2}{*}{$\begin{array}{l}\text { Geometric } \\
\text { Standard } \\
\text { Deviation }\end{array}$} \\
\hline & $\begin{array}{l}\text { Lower } \\
\text { Limit } \\
\left(\mathrm{Bq} / \mathrm{m}^{3}\right)\end{array}$ & $\begin{array}{l}\text { Upper Limit } \\
\left(\mathrm{Bq} / \mathrm{m}^{3}\right)\end{array}$ & $\begin{array}{l}\text { Representative } \\
\left(\mathrm{Bq} / \mathrm{m}^{3}\right)\end{array}$ & $\begin{array}{l}\text { Lower Limit } \\
\qquad(\mathrm{Bq})\end{array}$ & $\begin{array}{c}\text { Upper } \\
\text { Limit (Bq) }\end{array}$ & $\begin{array}{l}\text { Representative } \\
(\mathrm{Bq})\end{array}$ & \\
\hline${ }^{99} \mathrm{Tc}$ & $1.36 \mathrm{E}+09$ & $9.28 \mathrm{E}+09$ & $3.14 \mathrm{E}+09$ & $5.17 \mathrm{E}+12$ & $3.53 E+13$ & $1.19 \mathrm{E}+13$ & 1.93 \\
\hline${ }^{234} U$ & $8.20 \mathrm{E}+08$ & $5.60 \mathrm{E}+09$ & $1.89 \mathrm{E}+09$ & $3.12 \mathrm{E}+12$ & $2.13 \mathrm{E}+13$ & $7.18 \mathrm{E}+12$ & 1.93 \\
\hline${ }^{236} U$ & $1.20 \mathrm{E}+08$ & $8.21 \mathrm{E}+08$ & $2.78 \mathrm{E}+08$ & $4.56 \mathrm{E}+11$ & $3.12 \mathrm{E}+12$ & $1.06 \mathrm{E}+12$ & 1.93 \\
\hline${ }^{238} \mathrm{U}$ & $9.36 \mathrm{E}+09$ & $6.38 \mathrm{E}+10$ & $2.16 \mathrm{E}+10$ & $3.56 \mathrm{E}+13$ & $2.42 \mathrm{E}+14$ & $8.21 \mathrm{E}+13$ & 1.93 \\
\hline
\end{tabular}

The representative activity and geometric standard deviation were entered into the candidate waste cell of the approved baseline version of the Area 5 RWMS performance assessment model. The waste stream was evaluated with the Area 5 RWMS inventory disposed through the end of fiscal year (FY) 2009. The performance assessment model was run for 1,000 years (y) with 5,000 Monte Carlo realizations. At NDEP's request and given the NDEP's condition to assume the model remains the same regardless of the length of time it takes to reach the peak dose, a deterministic extended duration analysis to 6 million y was prepared to determine the peak dose and ${ }^{222} \mathrm{Rn}$ flux density. When the NDEP requested this special analysis, the NSO and NDEP verbally acknowledged that the magnitude and timing of peak results from the extended duration analysis represent model performance and should not be considered meaningful representations of future disposal site performance.

\section{Results}

The Savannah River Depleted Uranium Trioxide waste stream meets all performance objectives when the total volume is averaged over the volume of shallow land burial (SLB) waste disposed through FY 2009. The mean total effective dose (TED) for every scenario is less than the performance objective (Table 2).

Table 2. Performance assessment results for the shallow land burial waste disposed through FY 2009 and the FY 2009 inventory with the Savannah River Depleted Uranium Trioxide waste stream.

\begin{tabular}{|c|c|c|c|c|c|}
\hline & & & \multicolumn{2}{|c|}{ Mean } & \\
\cline { 5 - 6 } Performance Objective & Limit & $\begin{array}{c}\text { Time of } \\
\text { Maximum }\end{array}$ & $\begin{array}{c}\text { FY09 } \\
\text { Inventory }\end{array}$ & $\begin{array}{c}\text { FY09 } \\
\text { Inventory } \\
\text { with Waste } \\
\text { Stream }\end{array}$ & $\begin{array}{c}\text { Percent } \\
\text { Change }\end{array}$ \\
\hline Air Pathway/Transient Occupancy & $0.1 \mathrm{mSv} \mathrm{y}^{-1}$ & $1,000 \mathrm{y}$ & $1.3 \mathrm{E}-4$ & $1.5 \mathrm{E}-4$ & 15 \\
\hline Air Pathway/Resident & $0.1 \mathrm{mSv} \mathrm{y}^{-1}$ & $1,000 \mathrm{y}$ & $3.8 \mathrm{E}-4$ & $4.2 \mathrm{E}-4$ & 11 \\
\hline Air Pathway/Resident Farmer & $0.1 \mathrm{mSv} \mathrm{y}^{-1}$ & $1,000 \mathrm{y}$ & $5.0 \mathrm{E}-4$ & $5.6 \mathrm{E}-4$ & 12 \\
\hline Air Pathway/Cane Spring & $0.1 \mathrm{mSv} \mathrm{y}^{-1}$ & $1,000 \mathrm{y}$ & $6.3 \mathrm{E}-9$ & $6.9 \mathrm{E}-9$ & 10 \\
\hline Air Pathway/NNSS Boundary & $0.1 \mathrm{mSv} \mathrm{y}^{-1}$ & $1,000 \mathrm{y}$ & $1.3 \mathrm{E}-7$ & $1.5 \mathrm{E}-7$ & 15 \\
\hline All-Pathway/Transient Occupancy & $0.25 \mathrm{mSv} \mathrm{y}^{-1}$ & $1,000 \mathrm{y}$ & $3.7 \mathrm{E}-3$ & $3.7 \mathrm{E}-3$ & 0 \\
\hline All-Pathway/Resident & $0.25 \mathrm{mSv} \mathrm{y}^{-1}$ & $1,000 \mathrm{y}$ & $9.4 \mathrm{E}-4$ & $1.0 \mathrm{E}-3$ & 6 \\
\hline All-Pathway/Resident Farmer & $0.25 \mathrm{mSv} \mathrm{y}^{-1}$ & $1,000 \mathrm{y}$ & 0.014 & 0.015 & 7 \\
\hline All-Pathway/Cane Spring & $0.25 \mathrm{mSv} \mathrm{y}^{-1}$ & $1,000 \mathrm{y}$ & $8.7 \mathrm{E}-4$ & $9.0 \mathrm{E}-4$ & 3 \\
\hline All-Pathway/NNSS Boundary & $0.25 \mathrm{mSv} \mathrm{y}^{-1}$ & $1,000 \mathrm{y}$ & $8.8 \mathrm{E}-4$ & $9.1 \mathrm{E}-4$ & 3 \\
\hline
\end{tabular}


Table 2. Performance assessment results for the shallow land burial waste disposed through FY 2009 and the FY 2009 inventory with the Savannah River Depleted Uranium Trioxide waste stream (continued).

\begin{tabular}{|c|c|c|c|c|c|}
\hline & & & \multicolumn{2}{|c|}{ Mean } & \\
\cline { 5 - 6 } Performance Objective & Limit & $\begin{array}{c}\text { Time of } \\
\text { Maximum }\end{array}$ & $\begin{array}{c}\text { FY09 } \\
\text { Inventory }\end{array}$ & $\begin{array}{c}\text { FY09 } \\
\text { Inventory } \\
\text { with Waste } \\
\text { Stream }\end{array}$ & $\begin{array}{c}\text { Percent } \\
\text { Change }\end{array}$ \\
\hline Radon Flux Density & $0.74 \mathrm{~Bq} \mathrm{~m}^{-2} \mathrm{~s}^{-1}$ & $1,000 \mathrm{y}$ & 0.11 & 0.11 & 0 \\
\hline Postdrilling Intruder (All SLB) & $1 \mathrm{mSv}$ & $1,000 \mathrm{y}$ & $6.2 \mathrm{E}-3$ & $6.8 \mathrm{E}-3$ & 10 \\
\hline Intruder-Agriculture (All SLB) & $1 \mathrm{mSv}$ & $1,000 \mathrm{y}$ & 0.40 & 0.43 & 7 \\
\hline Drilling Intruder (All SLB) & $5 \mathrm{mSv}$ & $1,000 \mathrm{y}$ & $2.3 \mathrm{E}-3$ & $2.5 \mathrm{E}-3$ & 9 \\
\hline Construction Intruder (All SLB) & $5 \mathrm{mSv}$ & $1,000 \mathrm{y}$ & 2.8 & 3.1 & 11 \\
\hline
\end{tabular}

NOTE: Chronic intruder results are weighted with the probability of intrusion. All results are weighted by probabilistic length of institutional control.

Addition of the Savannah River Depleted Uranium Trioxide waste stream causes slight increases in the maximum results within the 1,000-y compliance period. The largest increase, 15 percent, is observed for the air pathway TED for the transient occupancy and Cane Spring scenarios.

The maximum model ${ }^{222} \mathrm{Rn}$ flux density occurs at approximately 2 million y (Figure 1 ). The performance objective is exceeded by 6,000 y. Addition of the Savannah River Depleted Uranium Trioxide waste stream slightly increases the peak ${ }^{222} \mathrm{Rn}$ flux density.

The maximum model resident all-pathways TED occurs at approximately 4 million y (Figure 2). The peak TED does not exceed the performance objective. Addition of the Savannah River Depleted Uranium Trioxide waste stream slightly increases the peak TED.

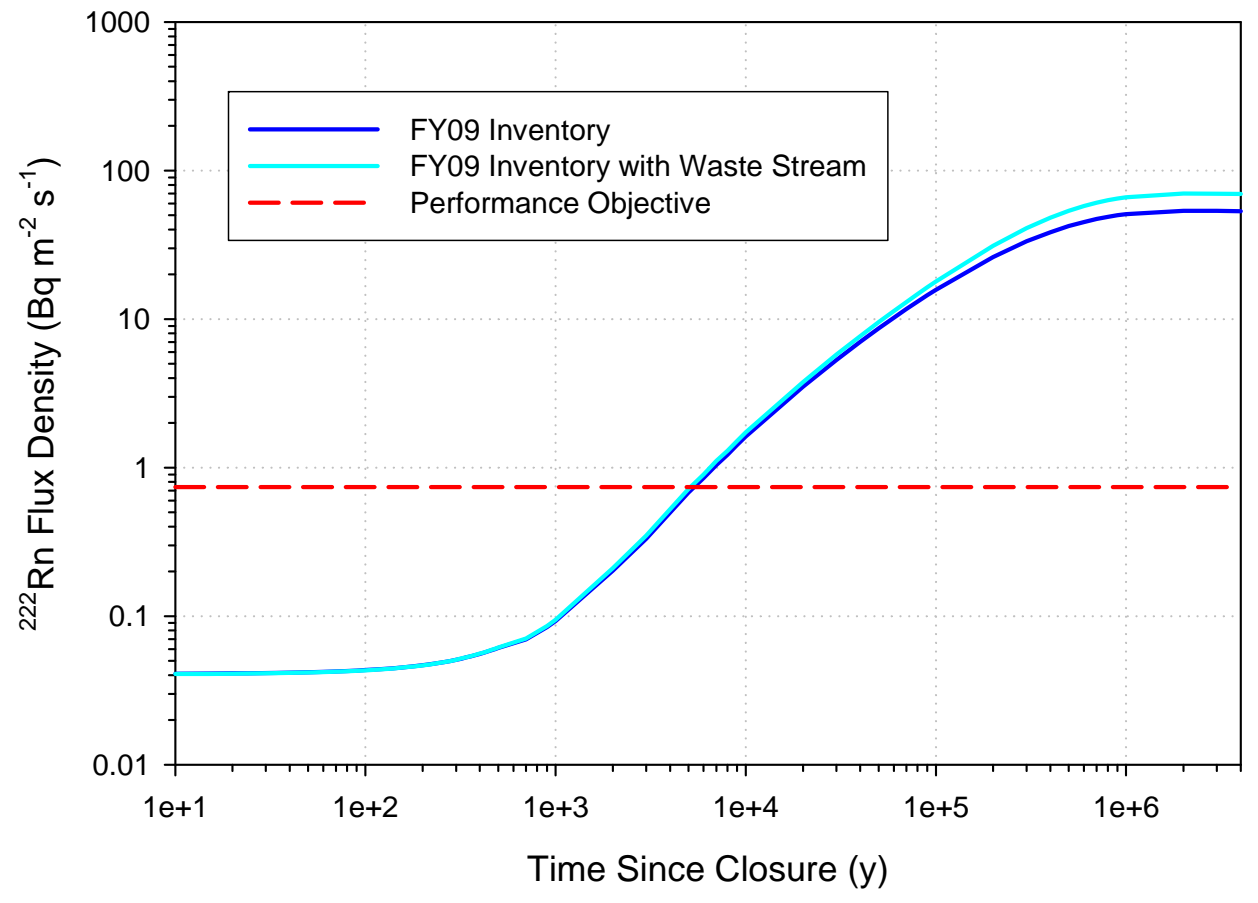

Figure 1. Time history of Area 5 RWMS ${ }^{222}$ Rn flux density for the inventory disposed though FY 2009 and the FY 2009 inventory with the Savannah River Depleted Uranium Trioxide. 


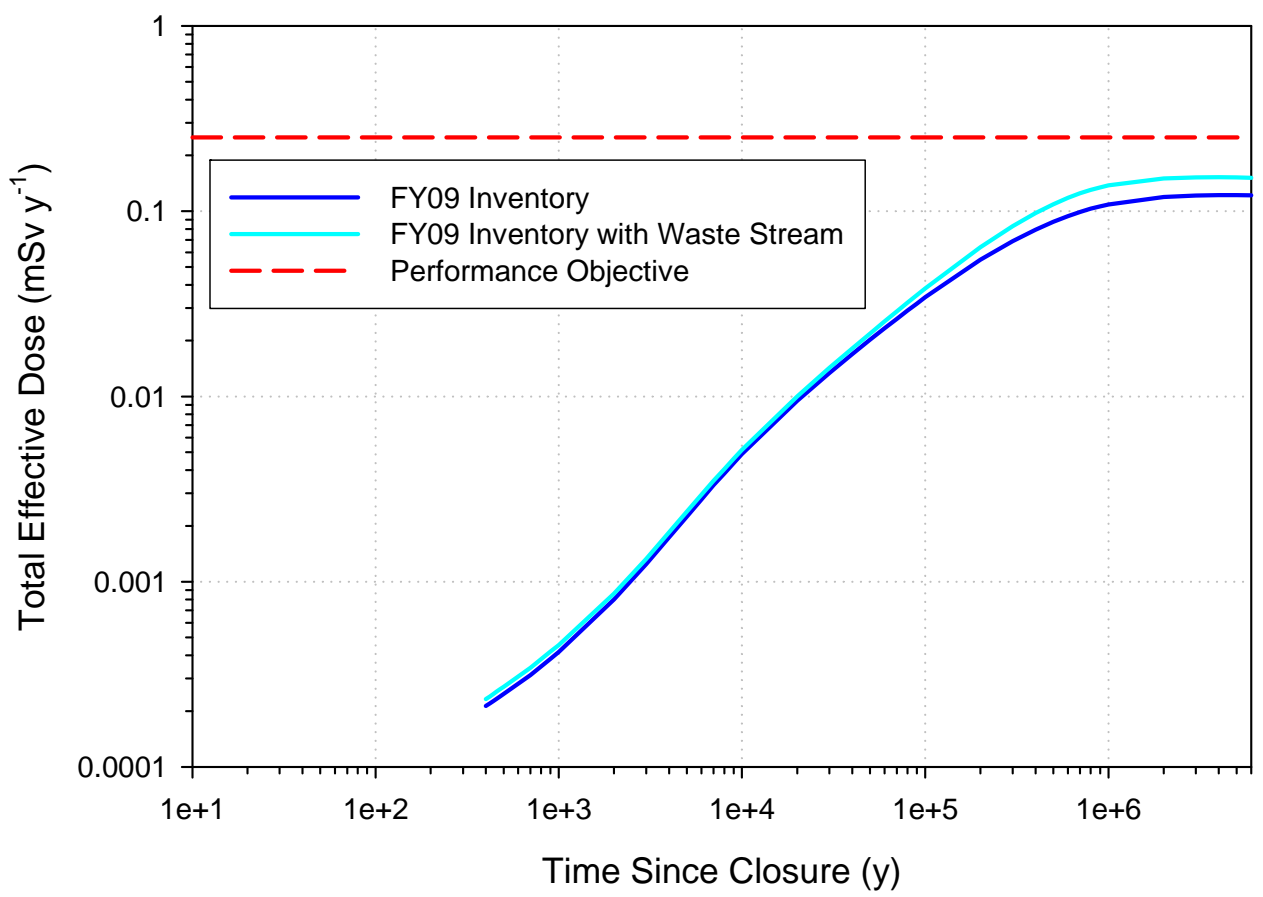

Figure 2. Time history of Area 5 RWMS resident scenario all pathways TED for the inventory disposed though FY 2009 and the FY 2009 inventory with the Savannah River Depleted Uranium Trioxide.

\section{Conclusion}

For the DOE Order 435.1 compliance period of 1,000 y, the Savannah River Depleted Uranium Trioxide waste stream is suitable for shallow land burial at the Area 5 RWMS without conditions.

Given the NDEP's requested model conditions, the SA demonstrates that the ${ }^{222} \mathrm{Rn}$ peak flux density will occur in about 2 million y and will exceed the performance objective in about 6,000 $\mathrm{y}$. The $0.25 \mathrm{mSv} \mathrm{y}^{-1}$ all-pathways resident scenario performance objective was not exceeded after reaching the 4 million-y peak dose. When the NDEP requested this special analysis, the NSO and NDEP verbally acknowledged the magnitude and timing of peak results from the extended duration analysis represent model performance and should not be considered meaningful representations of future disposal site performance.

\section{References}

Savannah River Nuclear Solutions, 2010. Depleted Uranium Trioxide Waste Profile. Aiken, SC. Rev. 2, September 16, 2010.

U.S Department of Energy, National Nuclear Security Administration Nevada Site Office, 2010. Nevada National Security Site Waste Acceptance Criteria. Las Vegas, NV. DOE/NV--325Rev. 8.

Reference herein to any specific commercial product, process, or service by trade name, trademark, manufacturer, or otherwise, does not necessarily constitute or imply its endorsement, recommendation, or favoring by the U.S. Government or any agency thereof. 